\title{
VISITATION AT KILL DEVIL HILLS
}

\section{David Essex}

I had watched with the snake's deaf fascination for the moving flute, as the spout's tubeworm hulaed across the water, evolved upon landfall into a trunk, the rest of the celestial elephant somewhere up in the thunderhead. Live as a wire, haphazard sliced blindly across the island, flaying the Orville Motor Hotel, leaving the interior untouched, the beds neat as the maids could make them, mirrors and watercolor seascapes staring from theatrical flats.

In the cathedral-quiet aftermath, sound siphoned up to the silent sky, the phone poles and the high-tension lines were hung with spuncandy-pink insulation. Ambulance gumballs winked 'Interesting . . . ' as they crept lightly among the dumbstruck lucky, who came out now, like night crawlers on a watered lawn.

Barbecueing in the power outage, we talked of $\mathrm{Oz}$ and God's macabre fondness for mystery, for the ambiguous object lesson. The tornado's one fatality was a local lady who was reported, probably apocryphally, to have turned eighty that day. She'd done, we agreed, as any of us wisely might have, and still the freezer fell a thousand feet and found her huddled in the ditch. 